\title{
Definitive Treatment for Locally Advanced Cervical Cancer: A Retrospective Analysis from A Singe Institution
}

\author{
Sumerya DURU BIRGI ${ }^{1}$, Melis GULTEKIN², Deniz YUCE ${ }^{3}$, Ferah YILDIZ ${ }^{2}$ \\ ${ }^{1}$ Gazi Yasargil Research and Training Hospital, Department of Radiation Oncology, Diyarbakir \\ ${ }^{2}$ Hacettepe University Faculty of Medicine, Department of Radiation Oncology, Ankara \\ ${ }^{3}$ Hacettepe University Faculty of Medicine, Department of Preventive Oncology, Ankara, TURKEY
}

\begin{abstract}
The primary aim of this study was to evaluate the long-term treatment outcomes of definitive chemoradiotherapy (CRT) of locally advanced cervical cancer and beside this to identify prognostic factors and related toxicities. Between February 2001 and September 2013, 327 patients were retrospectively evaluated. The median age was 56 years (range, 24-82 years). Ninety-five percent of patients had $\geq$ Stage IIB disease. External pelvic radiotherapy (RT) (45-50.4 Gy) and concomitant chemotherapy followed by 28 Gy in 4 fractions high dose rate brachytherapy was administered. Boost doses of 10-15 Gy were administered to $<2 \mathrm{~cm}$ lymph nodes (LNs) or distal parametrial involved sites. The median follow-up time was 68 months (range, 45-90 months). Two-, 5- and 10-year cancer specific survival (CSS) rates were 80\%, 68\%, and 65\%; disease-free survival (DFS) rates were 73\%, 66\%, and 64\%; local recurrence-free survival (LRFS) rates were 94\%, 92\%, and 91\%; loco-regional recurrence-free survival (LRRFS) were 92\%, 89\%, and 86\%; distant metastases-free survival (DMFS) were $81 \%, 76 \%, 75 \%$, respectively. In multivariate analysis, age, clinical stage and LN metastasis at diagnosis were independent prognostic factors for both CSS and DFS. Third month response to treatment was the most important prognostic factor for all end points in univariate and multivariate analysis. With the aggressive radiotherapeutic approach, it seems that distant metastases rather than locoregional recurrence determines the survival rates. Consolidation chemotherapy may be a good option after definitive CRT which needs to be supported with future phase III studies.
\end{abstract}

Keywords: Locally advanced, Cervix cancer, Chemoradiotherapy, Treatment response, Prognosis

\section{ÖZET}

\section{Lokal İleri Serviks Kanserinde Definitif Tedavi: Tek Bir Enstitüden Retrospektif Bir Analiz}

Çalışmamızın primer amacı, lokal ileri evre serviks kanserlerinde definitif kemoradyoterapi (KRT) ile tedavinin uzun dönem sonuçlarının değerlendirilmesi ve bunun yanında ilişkili prognostik faktörlerin ve toksisite sonuçlarının tanımlanmasıdır. Şubat 2001 ve Eylül 2013 tarihleri arasında, 327 hasta dosyası retrospektif olarak incelenmiştir. Ortanca yaş 56 yıldır (aralık, 24-82 yıl). Hastaların \%95'i zevre IIB hastalığa sahiptir. Eksternal pelvik radyoterapi (RT) (45-50.4 Gy) ile eş zamanlı kemoterapiyi takiben 4 fraksiyonda 28 Gy yüksek doz hızlı brakiterapi uygulanmıștır. Distal parametriyal tutulum olan bölgeye ya da <2 cm lenf nodlarına (LN) 10-15 Gy ek doz verilmiştir. Ortanca izlem süresi 68 aydır (aralık, 45-90 ay). Sırasıyla 2-, 5- ve 10-yıllık kanser spesifik sağkalım (CSS) oranları \%80, \%68 ve \%65; hastalıksız sağkalım oranları (DFS) \%73, \%66 ve \%64; lokal rekürrenssiz sağkalım (LRFS) oranları \%94, \%92 ve \%91; lokal-bölgesel rekürrenssiz sağkalım oranları (LRRFS) \%92, \%89 ve \%86; uzak metastazsız sağkalım oranları (DMFS) \%81, \%76 ve \%75’tir. Çok değişkenli analizde; yaş, klinik evre ve tanıda LN metastazı varlığı, CSS ve DFS için bağımsız prognostik faktör olarak bulunmuştur. Tek ve çok değişkenli analizde, 3. aydaki tedavi yanıı tüm sonlanım noktaları için anlamlı prognostik faktör olarak saptanmıştır. Agresif RT yaklaşımına karşın, sağkalım oranlarını lokal-bölgesel rekürrensten çok uzak metastazların belirlediği görülmektedir. Definitif KRT sonrası konsolidasyon kemoterapisi, faz III çalışmalarla desteklenmesi gereken iyi bir seçenek olabilir.

Anahtar Kelimeler: Lokal ileri evre, Serviks kanseri, Kemoradyoterapi, Tedavi yanıtı, Prognoz 


\section{INTRODUCTION}

Cervical cancer is the third most common malignancy after breast and colorectal cancers and the fourth leading cause of cancer death in women worldwide. ${ }^{1}$ In the year 2008 cervix cancer was ranked 10th among the most frequent tumors in females in the United States with a rate of 9/100.000. ${ }^{2}$

While surgery and radiotherapy (RT) produce similar outcomes in early stages, concurrent chemoradiotherapy (CRT) is the standart of care in locally advanced disease. ${ }^{3-8}$ In the International Federation of Gynecology and Obstetrics (FIGO) 26th Annual Report, it was shown that stage of the disease and lymph node (LN) involvement were the most important prognostic factors. ${ }^{9}$ In the early studies, the most important predictors for recurrence and survival were expressed as the presence of positive para-aortic (PA) LNs in patients with locally advanced disease treated with definitive RT. ${ }^{10-11}$ In patients with pelvic confined disease on the other hand, most important prognostic factors were the pelvic nodal involvement and tumor size. Other clinical prognostic parameters were indicated as clinical stage, age, and performance status. ${ }^{10}$ Low hemoglobin $(\mathrm{Hb})$ levels on the other hand were also shown to be associated with decreased 3-year survival. ${ }^{12}$

The main problem in locally advanced disease was local or regional recurrence or resistance of the disease. Pelvic recurrence forms two thirds of the recurrent disease after treatment. Hematogenous metastasis on the other hand is very rare at diagnosis and the most common sites of metastasis were the lung, followed by bone, the peritoneal cavity and supraclavicular nodes. ${ }^{13-14}$

The primary aim of this retrospective study was to investigate treatment results of cervical cancer patients who were treated with curative intent at a single institution. All patients were treated with concomitant chemotherapy and external beam RT (EBRT) followed by high dose rate (HDR) intracavitary brachytherapy (BRT). Secondary aims were to determine the prognostic factors and treatment related toxicities.

\section{PATIENTS AND METHODS}

\section{Patients}

A total of 327 patients with FIGO stage IB-IVA cervical cancer treated with primary concurrent CRT between February 2001 and September 2013 were retrospectively evaluated. All cancers were histologically confirmed. None of the patients had received prior radiotherapy. Patients with evidence of enlarged paraaortic LNs, known distant metastatic disease at initial presentation, or referred for recurrent disease were excluded. All patients had gynecological examination under general anesthesia and they were clinically staged according to the FIGO staging criteria. Pelvic magnetic resonance imaging (MRI) and thoracic and abdominal computed tomography (CT) or positron emission tomography (PET)/CT after the year 2008 were the routine imaging techniques performed for all patients in order to detect or rule out distant metastases. All patients had adequate bone marrow, renal and liver function. This retrospective study was approved by the institutional ethics committee and was conducted in compliance with principles of Helsinki declaration.

\section{Treatment}

All patients received EBRT to a total dose of 4550.4 Gy in 1.8-2.0 Gy daily fractions delivered with pelvic box technique using 6-18 MV X-rays. When there was pelvic side wall involvement or LNs highly suspicious of containing metastatic disease detected by imaging techniques but $<2 \mathrm{~cm}$ in the maximum diameter, 10-15 Gy boost doses were administered in addition. According to our institute's policy, LN dissection (LND) prior to EBRT was routine practice in patients with LNs more than $2 \mathrm{~cm}$ in diameter. Concomitant chemotherapy was basically in the form of $40 \mathrm{mg} / \mathrm{m}^{2}$ cisplatinum on weekly basis during EBRT. HDR BRT with 7 Gy per fraction prescribed to either point A or high risk clinical target volume (HRCTV) to a total dose of 28 Gy was applied to all patients.

EBRT was given two dimensionally (2D) in 236 (72\%) patients. In this 2D-RT technique, upper border was at L4-L5 level, lower border was below the obturator foramen and lateral borders as 2 $\mathrm{cm}$ to lateral margin of the bony pelvis. In left and 
right fields the posterior border was defined as the line between sacral 2 and 3 vertebras and the anterior border was the line just in front of the symphisis pubis. Ninety-one (28\%) patients received three dimensional (3D) RT and target volumes including all cervical and entire uterus, bilateral parametrium and proximal vagina as primary clinical target volume (CTV) and internal iliac, external iliac and presacral lymphatics as lymphatic CTV were contoured based on the Radiation Therapy Oncology Group (RTOG) contouring atlas. ${ }^{15}$

Image based 3D treatment planning of BRT was available in our department since May 2012 and only $13 \%$ of our patients included in this study were treated with this technique. In 2D-BRT, all patients were evaluated with gynecological examination in the 3rd week of EBRT to determine whether there was adequate tumour regression and when it was so the first HDR BRT procedure was applied at the beginning of 4th week and followed by the rest 3 fractions once a week during the remaining and following EBRT. The dose was prescribed to point A defined by the Manchester system. ${ }^{16}$ In 3D-BRT patients were evaluated both with gynecological examination and pelvic MRI at the end of EBRT and BRT was administered every other day as $28 \mathrm{~Gy}$ in 4 fractions. In this technique HRCTV, intermediate risk CTV (IRCTV) and critical organs like rectum, bladder and the sigmoid were outlined as proposed by the "Groupe Européen de Curiethérapie and the European Society for Radiotherapy and Oncology " (GEC-ESTRO) on CT scans. ${ }^{17-18}$ The prescribed dose was 7 Gy to HRCTV and the optimisation was made to obtain $90 \%$ of the HRCTV (D90) should receive at least $100 \%$ of the prescribed dose and $100 \%$ volume of IRCTV should receive at least $50 \%$ of the dose. With this dose delivery combined with EBRT, it is assumed that the HRCTV receives 85-90 Gy and IRCTV at least 60 Gy EQD2 (equivalent dose in 2 Gy fractions) when $\alpha / \beta$ of cervical cancer taken as 10 . Dose optimization was also made for $2 \mathrm{cc}$ of bladder volume received $\leq 7 \mathrm{~Gy}, 2 \mathrm{cc}$ of rectum and sigmoid volume as $\leq 5 \mathrm{~Gy}$.

\section{Follow up}

Patients were assessed weekly for acute toxicity during CRT. After the completion of CRT to as- sess treatment response, detailed gynecological examination at 1 month and pelvic MRI and/or PET/ $\mathrm{CT}$ in addition to Pap smear at 3 months were performed in all patients. Response assessment was done according to the Response Evaluation Criteria in Solid Tumors (RECIST)) criteria. ${ }^{19} \mathrm{~A}$ complete response $(\mathrm{CR})$ was defined as the complete disappearance of all target lesions and the absence of new lesions. A partial response (PR) was defined as at least a $30 \%$ reduction in the sum of the longest dimensions of the target lesions. Progressive disease (PD) was defined as at least a $20 \%$ increase in the sum of the longest dimensions of the target lesions or the development of new lesions. Stable disease (SD) defined as neither sufficient shrinkage (compared to baseline) to qualify for CR or PR nor sufficient increase (taking as reference the smallest sum of diameters at baseline or while on study, whichever is smallest) to qualify for progressive disease (PD).

When there was a complete tumor response, gynecological examination, annual smear test and imaging studies when necessary were done every 3 months for the first 2 years, every 6 months until fifth years and annualy thereafter. During follow up, patients were evaluated for local, regional or distant recurrence, and treatment related toxicities. Acute and late toxicity was scored using European Organisation for Research and Treatment of Cancer (EORTC)/RTOG scoring system. ${ }^{20}$

\section{Statistical Analysis}

Statistical analysis was performed using PASW Statistics for Windows v.18.0 (SPSS, Inc., Chicago, IL). All survival analyses were done using by the Kaplan-Meier method and a value of $\mathrm{p} \leq 0.05$ was considered statistically significant. Log-rank test was used to determine following prognostic factors: age ( $\leq 56$ years vs. $>56$ years), Hb level before RT ( $<11 \mathrm{~g} / \mathrm{dL}$ vs. $\geq 11 \mathrm{~g} / \mathrm{dL}$ ), histological subtype (squamous cell carcinoma-SCC vs. other), LN metastasis at diagnosis (yes vs. no), stage (<IIB vs. $\geq$ IIB), LND status (yes vs. no), hydronephrosis (yes vs. no), and 3rd month response status (complete vs. other). Multivariate analysis was performed using the Cox Regression analysis. Overall survival (OS) was defined as the time from end of the treat- 
ment until death from any cause. Time to relapse or death from any cause, which ever comes first was taken for disease-free survival (DFS). Time to develop local, regional or distant recurrence was taken for local recurrence-free survival (LRFS), locoregional recurrence-free survival (LRRFS) and distant metastases-free survival (DMFS). We also calculated cause-specific survival (CSS) which was defined as time to relapse or death from cancer including complications of the treatment, which ever comes first.

\section{RESULTS}

\section{Patient and Tumor Characteristics}

Clinicopathological characteristics of 327 patients included in this study are shown in Table 1. Median age of the patients was 56 years (range, 2482 years) and more than $90 \%$ were over 40 years. Three hundred and nine patients $(95 \%)$ had stage $\geq$ IIB disease. The majority of patients $(90 \%)$ were with squamous cell carcinoma (SCC). Median maximum tumor size at the time of diagnosis was $5 \mathrm{~cm}$ (range, 1-11 cm) and median maximum LN size was $2.4 \mathrm{~cm}$ (range, $0.8-7 \mathrm{~cm}$ ). One hundred and one patients $(31 \%)$ were considered as having clinical LN metastasis and LN positivity was detected by MRI in 67 (66\%), MRI and PET/CT in 27 (27\%), and PET/CT in $2(0.2 \%)$ cases. Two hundred and fifty-one (77\%) patients were having $\mathrm{Hb}$ level $>11 \mathrm{~g} / \mathrm{dl}$ at the beginning of RT. All patients were given transfusions in order to increase serum $\mathrm{Hb}$ level $>11 \mathrm{~g} / \mathrm{dl}$ when necessary before and/or during treatment.

\section{Treatment Parameters}

Treatment details are shown in Table 2. One hundred and thirty (40\%) patients underwent LND, mostly administered extraperitonealy (82\%). Eighteen patients $(5 \%)$ were treated with neoadjuvant chemotherapy with different protocols and 12 out of these patients were referred for RT with PR and 4 with SD after neoadjuvant chemotherapy.

The median total EBRT dose was 50.4 Gy (range, 45-50.4 Gy) and 39 (12\%) patients were given 1015 Gy boost dose due to stage IIIB disease and/or LN involvement. HDR BRT dose was mostly 28

\begin{tabular}{|c|c|c|}
\hline Characteristics & $\mathbf{n}$ & $\%$ \\
\hline \multicolumn{3}{|l|}{ Age (years) } \\
\hline$\leq 56$ & 186 & 57 \\
\hline$>56$ & 141 & 43 \\
\hline \multicolumn{3}{|l|}{ Tumor Histology } \\
\hline Squamous cell carcinoma & 295 & 90 \\
\hline Adenocarcinoma & 24 & 7 \\
\hline Clear cell carcinoma & 3 & 1 \\
\hline Others & 5 & 2 \\
\hline \multicolumn{3}{|l|}{ Grade } \\
\hline I (well differantiated) & 38 & 12 \\
\hline II (moderate differantiated) & 53 & 16 \\
\hline III (poor differantiated) & 64 & 20 \\
\hline Unknown & 172 & 52 \\
\hline \multicolumn{3}{|l|}{ Tumor Size (cm) } \\
\hline$\leq 4$ & 68 & 21 \\
\hline$>4$ & 252 & 77 \\
\hline Unknown & 7 & 2 \\
\hline \multicolumn{3}{|l|}{ Parametrial Involvement } \\
\hline Positive & 293 & 89 \\
\hline Negative & 33 & 10 \\
\hline Unknown & 1 & 1 \\
\hline \multicolumn{3}{|l|}{ Lymph Node Involvement } \\
\hline Positive & 101 & 31 \\
\hline Negative & 226 & 69 \\
\hline \multicolumn{3}{|l|}{ FIGO Stage (2009) } \\
\hline IB2 & 8 & 2 \\
\hline$\| \mathrm{A} 2$ & 10 & 3 \\
\hline IIB & 182 & 56 \\
\hline$\| I A$ & 16 & 5 \\
\hline IIIB & 88 & 27 \\
\hline IVA & 23 & 7 \\
\hline \multicolumn{3}{|l|}{ Hb Level } \\
\hline$\leq 11$ & 76 & 23 \\
\hline$>11$ & 251 & 77 \\
\hline \multicolumn{3}{|c|}{$\begin{array}{l}\text { Abbreviatons: } \mathrm{FIGO}=\text { International Federation of Gynecology and } \\
\text { Obstetrics, } \mathrm{Hb}=\text { Hemoglobin }\end{array}$} \\
\hline
\end{tabular}

Gy in 4 fractions (93\%). Only in 23 patients, BRT fraction doses were reduced to 6-6.5 Gy in order to keep rectum and bladder doses in tolerance limits.

Concomitant weekly cisplatin chemotherapy was given to 288 of 296 patients (91\%) during EBRT while remaining 8 patients received carboplatin and other different schemes due to medical contraindications to cisplatin. One hundred and eighty-one patients $(55 \%)$ received at least 4 cycles of concomitant chemotherapy while $34 \%$ of patients received less than 4 cycles due to the toxicity issues. 
International Journal of Hematology and Oncology

Table 3. Univariate analysis of prognostic factors for cancer-spesific survival, disease-free survival, local recurrence-free survival, locoregional recurrence-free survival, distant metastases-free survival and overall survival

\begin{tabular}{|c|c|c|c|c|c|}
\hline Survival & Factor & 2 years $(\%)$ & 5 years $(\%)$ & 10 years $(\%)$ & $\mathbf{p}$ \\
\hline \multirow[t]{15}{*}{ css } & Hydronephrosis & & & & \\
\hline & Yes & 66 & 48 & 47 & 0.003 \\
\hline & No & 82 & 72 & 68 & \\
\hline & Lymph node metastasis & & & & \\
\hline & Yes & 73 & 56 & 50 & 0.01 \\
\hline & No & 82 & 72 & 70 & \\
\hline & Stage & & & & \\
\hline & $<\| \mathrm{B}$ & 78 & 77 & 76 & $<0.0001$ \\
\hline & $\geq \| \mathrm{IB}$ & 80 & 68 & 65 & \\
\hline & LND & & & & \\
\hline & Yes & 88 & 72 & 70 & 0.038 \\
\hline & No & 75 & 65 & 61 & \\
\hline & 3rd month response & & & & \\
\hline & Complete & 83 & 72 & 69 & $<0.0001$ \\
\hline & Other & 60 & 46 & 42 & \\
\hline \multirow[t]{12}{*}{ DFS } & Hydronephrosis & & & & \\
\hline & Yes & 62 & 51 & 51 & 0.009 \\
\hline & No & 76 & 68 & 67 & \\
\hline & Lymph node metastasis & & & & \\
\hline & Yes & 62 & 51 & 47 & 0.001 \\
\hline & No & 79 & 71 & 70 & \\
\hline & Stage & & & & \\
\hline & $<\| \mathrm{B}$ & 77 & 76 & 76 & $<0.0001$ \\
\hline & $\geq \| \mathrm{B}$ & 74 & 65 & 64 & \\
\hline & 3rd month response & & & & \\
\hline & Complete & 77 & 69 & 67 & 0.001 \\
\hline & Other & 55 & 44 & 43 & \\
\hline \multirow[t]{6}{*}{ LRFS } & Histology & & & & \\
\hline & SCC & 95 & 93 & 93 & 0.018 \\
\hline & Others & 82 & 81 & 81 & \\
\hline & 3rd month response & & & & \\
\hline & Complete & 95 & 93 & 93 & 0.012 \\
\hline & Other & 86 & 82 & 82 & \\
\hline \multirow[t]{3}{*}{ LRRFS } & 3rd month response & & & & \\
\hline & Complete & 95 & 92 & 89 & $<0.0001$ \\
\hline & Other & 78 & 71 & 71 & \\
\hline \multirow[t]{9}{*}{ os } & Lymph node metastasis & & & & \\
\hline & Yes & 61 & 42 & 30 & 0.008 \\
\hline & No & 71 & 57 & 47 & \\
\hline & Hb level & & & & \\
\hline & $<11$ & 54 & 37 & 29 & 0.002 \\
\hline & $\geq 11$ & 72 & 58 & 46 & \\
\hline & 3rd month response & & & & \\
\hline & Complete & 71 & 54 & 43 & 0.001 \\
\hline & Other & 55 & 41 & 38 & \\
\hline \multirow[t]{12}{*}{ DMFS } & Hydronephrosis & & & & \\
\hline & Yes & 72 & 60 & 60 & 0.023 \\
\hline & No & 82 & 79 & 78 & \\
\hline & Lymph node metastasis & & & & \\
\hline & Yes & 70 & 65 & 61 & 0.001 \\
\hline & No & 85 & 81 & 81 & \\
\hline & Stage & & & & \\
\hline & $<\| \mathrm{B}$ & 78 & 77 & 77 & 0.001 \\
\hline & $\geq \| \mathrm{B}$ & 81 & 76 & 75 & \\
\hline & 3rd month response & & & & \\
\hline & Complete & 84 & 79 & 78 & 0.001 \\
\hline & Other & 64 & 57 & 57 & \\
\hline
\end{tabular}

Abbreviations: CSS= Cancer-spesific survival, DFS= Disease-free survival, LRFS= Local recurrence-free survival, LRRFS= Locoregional recurrencefree survival, $\mathrm{OS}=$ Overall survival, $L N D=$ Lymph node dissection, $S C C=$ Squamous cell cancer 
Table 4. Multivariate analysis of prognostic factors for cancer-spesific survival, disease-free survival, local recurrence-free survival, locoregional recurrence-free survival and distant metastases-free survival.

\begin{tabular}{|c|c|c|c|c|}
\hline Survival & Factor & Hazard Ratio & $95 \% \mathrm{Cl}$ & $\mathbf{p}$ \\
\hline \multirow[t]{8}{*}{ CSS } & $\begin{array}{l}\text { Age }(y) \\
\quad \leq 56 \\
>56 \\
\text { Lymph node metastasis }\end{array}$ & $\begin{array}{l}1 \\
1.6\end{array}$ & $1.043-2.475$ & 0.032 \\
\hline & $\begin{array}{l}\text { Yes } \\
\text { No }\end{array}$ & $\begin{array}{l}1 \\
0.588\end{array}$ & $0.374-0.926$ & 0.022 \\
\hline & Stage & & & \\
\hline & $<$ IIB & 1 & $1.071-2.042$ & 0.017 \\
\hline & $\geq I I B$ & 1.479 & & \\
\hline & 3rd month response & & & \\
\hline & Complete & 1 & $0.984-2.032$ & 0.029 \\
\hline & Other & 1.41 & & \\
\hline \multirow[t]{12}{*}{ DFS } & Age (y) & & & \\
\hline & $\leq 56$ & 1 & $1.057-2.478$ & 0.027 \\
\hline & $>56$ & 1.618 & & \\
\hline & Lymph node metastasis & & & \\
\hline & Yes & 1 & $0.313-0.755$ & 0.001 \\
\hline & No & 0.487 & & \\
\hline & Stage & & & \\
\hline & $<\| \mathrm{B}$ & 1 & $1.055-2.013$ & 0.022 \\
\hline & $\geq \| \mathrm{BB}$ & 1.457 & & \\
\hline & 3rd month response & & & \\
\hline & Complete & 1 & $1.133-2.870$ & 0.013 \\
\hline & Other & 1.804 & & \\
\hline \multirow[t]{3}{*}{ LRFS } & 3rd month response & & & \\
\hline & Complete & 1 & $4.767-50.519$ & $<0.0001$ \\
\hline & Other & 15.519 & & \\
\hline \multirow[t]{3}{*}{ LRRFS } & 3rd month response & & & \\
\hline & Complete & 1 & $3.041-17.551$ & $<0.0001$ \\
\hline & Other & 7.306 & & \\
\hline \multirow[t]{6}{*}{ DMFS } & Lymph node metastasis & & & \\
\hline & Yes & 1 & $0.298-0.827$ & 0.007 \\
\hline & No & 0.496 & & \\
\hline & 3rd month response & & & \\
\hline & Complete & 1 & $1.203-3.554$ & 0.009 \\
\hline & Other & 2.068 & & \\
\hline
\end{tabular}

Abbreviations: $\mathrm{Cl}=$ Confidence interval, CSS= Cancer-spesific survival, DFS= Disease-free survival, LRFS= Local recurrence-free survival, LRRFS= Locoregional recurrence-free survival, DMFS= Distant metastases-free survival

was observed as dysuria in 8 patients, hematuria in 3 patients, vesicovaginal fistula in 4 patients and urinary incontinence in 5 patients. Late GIS toxicity was observed as rectal bleeding in $21(6 \%)$ patients, rectovaginal fistula in $4(1 \%)$ patients, intestinal obstruction in $1(0.3 \%)$ patient, and intestinal perforation in $1(0.3 \%)$ patient. The patient who developed bowel perforation died due to this complication.

\section{DISCUSSION}

Concomittant CRT is the standart approach in locally advanced cervical carcinoma. ${ }^{21,22}$ With concurrent CRT, $10 \%$ increase at OS and 13\% increase at progression free survival (PFS) have been shown with a risk of increasing grade 3-4 toxicity at the same time. ${ }^{21}$ In a recent metaanalysis of randomized trials, Datta et al. demonstrated that concomittant chemotherapy improved the $\mathrm{CR}$ rates by a factor of $10.2 \%$, locoregional control rates by $8.4 \%$ and OS rates by $7.5 \% .{ }^{23}$ In the phase III 
A. Overall survival

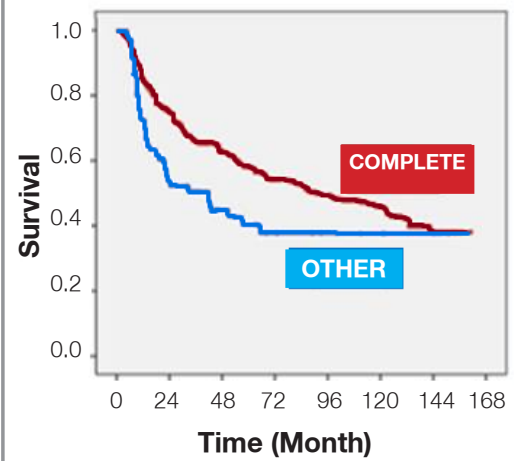

B. Disease-free survival

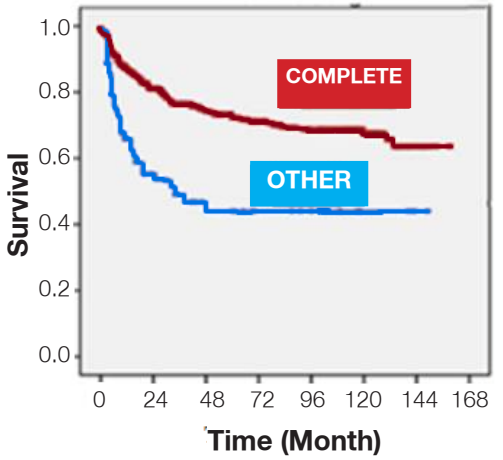

C. Local recurrence-free survival

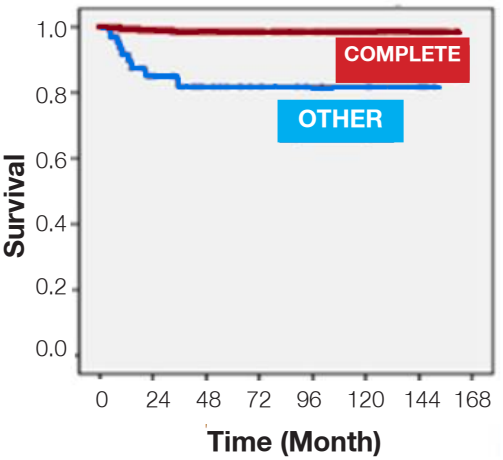

D. Loco-regional recurrence-free survival

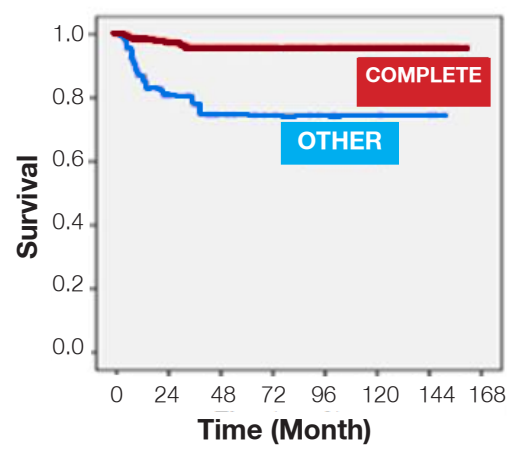

E. Distant metastasis-free survival

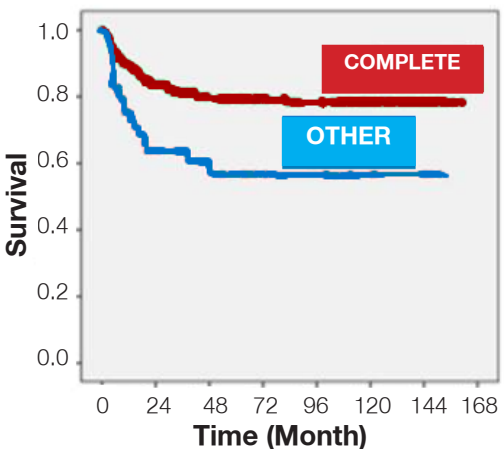

Figure 1. Kaplan-Meier curves of overall survival (A), disease-free survival (B), local recurrence-free survival (C), locoreginal recurrence-free survival (D) and distant metastases-free survival (E) according to 3rd month treatment response

Gynecologic Oncology Group (GOG) 120 study, the 2-, 5-, and 10-year PFS rates in patients with stage IIB-IVA disease who received concurrent cisplatin-based CRT were $63 \%, 58 \%$ and $46 \%$, respectively. ${ }^{24}$ In our study, the corresponding DFS rates for 2-, 5-, and 10-years were found as $73 \%$, $66 \%$ and $64 \%$ which seems to be quite higher than GOG 120 study. However a more recent study by Dueraz-Gonzalez et al., the 2- and 5-year PFS rates in patients with stage IIB-IVA disease were reported as $70 \%$ and $60 \%$, respectively, which is very similar to our study. ${ }^{25}$

In our study, local and locoregional failure rates were found to be $6.6 \%$ and $8.3 \%$, respectively. These figures were reported to be around $18 \%$ in RTOG 90-01 and 21-22\% in GOG 120 studies. ${ }^{8}$ ${ }^{24}$ The median EBRT dose in our study was 50.4 Gy and patients with more than $2 \mathrm{~cm}$ LNs were referred for LND. Patients with having either stage
IIIB disease and/or involved LNs were also treated with additional 10-15 Gy EBRT dose. The total EQD2 dose in our study was $\geq 85$ Gy which is higher than the EQD2 doses of RTOG and GOG trials in which the total EQD2 doses were around 85 Gy and $81 \mathrm{~Gy}$, respectively. We think that high doses to both HRCTV and distal parametrium and LNs containing metastasis in addition to LND in patients with bulky LN metastasis led us to achieve these high locoregional control rates.

The most significant prognostic factor in our study for all oncological end points was the presence of complete clinical disappearance of tumor at the 3rd month follow up visit. Cancer mortality rate was increased up to $40 \%$ in patients without CR at three months. There was an increase of 1.8 times in any recurrence risk, 15 times in local progression risk, 7.3 times in locoregional progression risk and 2 times in distant metastasis risk when there 
was no CR after concurrent CRT. In a similar study by Grisby et al, 5-year CSS was reported to be around $80 \%$ in patients with functional CR detected with PET/CT and it was $32 \%$ when there was no functional CR. ${ }^{26}$ Similar results were shown in other studies. ${ }^{27,28}$ However in a recent retrospective study by Kim et al., around $60 \%$ of patients with less than $2 \mathrm{~cm}$ residual disease after CRT showed spontaneous regression without any salvage treatment. ${ }^{29}$ Close surveillance can be performed in a subgroup of patients with minor residual disease after CRT but prospective trials are needed to determine which patients can be left without salvage surgery. Until that time it is possible to say that post-treatment clinical and functional response rate is the most important prognostic factor in locally advanced cervical cancer.

The age was another prognostic factor in multivariate analysis determining the CSS and DFS in our study besides the other well known prognostic factors as LN metastasis, stage of the disease and low $\mathrm{Hb}$ level. The prognostic efficacy of age in locally advanced cervical cancer is controversial. According to some reports, age is not a prognostic factor in cervical cancer. ${ }^{30}$ Other reports on the other hand demonstrated worse survival in women younger than $35-40$ years of age. ${ }^{31}$ In a study by Mittchell et al. on the other hand tumor recurrence and death from cancer were more common in the elderly patients. ${ }^{32}$ The median age in our study was 56 years and we found that patients older than 56 years showed 1.6 times higher risk of disease recurrence and 1.6 times higher risk of cancer death when compared to the younger counterparts. When we looked at our data we found that there were no significant differences in terms of prognostic or treatment related factors between the 2 age groups, only patients younger than 56 years had significantly higher LN metastasis. Though having less lymphatic metastasis, patients older than 56 years showed worse prognosis and we do not know the reason.

Another prognostic factor for LRFS was histopathological subtype other than SCC. In our study SCC histology was found as good prognostic factor for LRFS. The median LRFS in patients with SCC was 41.5 months and it was 26 months in patients other than SCC histology. In a study by Rose et al., adeno- and adenosquamous carcinomas of the cervix were associated with worse OS when treated with RT alone but with similar PFS and OS compared to SCCs of the cervix when treated with cisplatin-based CRT. ${ }^{33}$ However in another study by Yokoi et al., patients with adeno- and adenosquamous cancer of the cervix exhibited significantly shorter OS and PFS than the patients with SCC of the cervix. ${ }^{34}$ There was only LRFS disadvantage of histology other than SCC in our study without any detrimental effect on the other oncological outcomes.

The majority of our patients were having either stage IIB or IIIB disease. Eighty percent of our patients experienced CR 3 months after concurrent CRT. With a median follow up of 68 months, the LRRFS was $89 \%$ at 5 years. However the corresponding DMFS rate was $76 \%$. In a retrospective study by Jelavic TB et al., patients treated with concurrent CRT and a consolidation with four cycles of the same drug combination as an adjuvant, showed $86.4 \%$ DMFS after a median follow-up of 96 months. ${ }^{35}$ In another study by GOG, Southwest Oncology Group (SWOG) and RTOG, Peters et al. showed highly significant PFS and OS rates with adddition of concomitant and consolidation chemotherapy in patients with high risk features after radical hysterectomy. ${ }^{21}$

The weakest part of our study is its retrospective nature. We cannot exclude potencial sources of biases in this aspect. Moreover, the treatment strategies are heterogenous regarding the use of neoadjuvant chemotherapy, concurrent chemotherapy scheme and RT technique etc. However the majority of our patients were treated with standart approach as having concomittant weekly basis CRT with standard external and BRT doses. In addition all patients were followed up obeying strict procedures as thorough gynecological examination, MRI and/or PET/CT imaging at certain times after treatment.

In conclusion, though retrospective, our study confirms that the response to treatment is the major prognostic factor in locally advanced cervical cancer and the majority of patients show CR after concurrent CRT. The LRRFS in these patients seems quite satisfactory however distant metastases deteriorate the oncologic outcomes. Consolidation 
chemotherapy may be an option to reduce the rate of distant metastases in high risk patients. Hovewer well designed phase III studies are needed in this regard.

\section{REFERENCES}

1. Siegel R, Ma J, Zou Z, et al. Cancer statistics. CA Cancer J Clin 64: 9-29, 2014.

2. Jemal A, Siegal R, Xu J, et al. Cancer Statistics. CA Cancer J Clin 60: 277-300, 2010.

3. Landoni F, Maneo A, Colombo A, et al. Randomised study of radical surgery versus radiotherapy for stage Ib-lla cervical cancer. Lancet 350: 535-540, 1997.

4. Whitney CW, Sause W, Bundy BN, et al. Randomized comparison of fluorouracil plus cisplatin versus hydroxyurea as an adjunct to radiation therapy in stage IIB-IVA carcinoma of the cervix with negative para-aortic lymph nodes: a Gynecologic Oncology Group and Southwest Oncology Group study. J Clin Oncol 17: 1339-1348, 1999.

5. Rose PG, Bundy BN, Watkins EB, et al. Concurrent cisplatinbased radiotherapy and chemotherapy for locally advanced cervical cancer. N Engl J Med 340: 1144- 1153, 1999.

6. Morris M, Eifel PJ, Lu J, et al. Pelvic radiation with concurrent chemotherapy compared with pelvic and para-aortic radiation for high-risk cervical cancer. N Engl J Med 340: 11371143,1999

7. Pearcey R, Brundage M, Drouin P, et al. Phase III trial comparing radical radiotherapy with and without cisplatin chemotherapy in patients with advanced squamous cell cancer of the cervix. J Clin Oncol 20: 966-972, 2002.

8. Eifel PJ, Winter K, Morris M, et al. Pelvic irradiation with concurrent chemotherapy vs pelvic and paraaortic irradiation for high risk cervical cancer: an update of radiation therapy oncology group trial (RTOG 90-01). J Clin Oncol 22: 872-880, 2004.

9. Quinn MA, Benedet JL, Odicino F, et al. Carcinoma of the cervix uteri. FIGO 26th annual report on the results of treatment in gynecological cancer. Int J Gynaecol Obstet 95 Suppl 1:S43, 2006.

10. Delgado G, Bundy BN, Fowler WC, et al. A prospective surgical pathological study of Stage I squamous carcinoma of the cervix. A Gynecologic Oncology Group study. Gynecol Oncol 36: 314-320, 1989.

11. Stehman FB, Bundy BN, Disaia PJ, et al. Carcinoma of the cervix treated with radiation therapy. I. A multivariate analysis of prognostic variables in the Gynecologic Oncology Group. Cancer 67: 2776-2785, 1991.

12. Haensgen G, Krause U, Becker A, et al. Tumor hypoxia, p53, and prognosis in cervical cancers. Int J Radiat Oncol Biol Phys 50: 865-872, 2001

13. Fagundes H, Perez CA, Grigsby PW, et al. Distant metasta- ses after irradiation alone in carcinoma of the uterine cervix. Int J Radiat Oncol Biol Phys 24: 197-204, 1992.

14. Kim RY, Weppelmann B, Salter MM, et al. Skeletal metastases from cancer of the uterine cervix. Frequency, patterns, and radio-therapeutic significance. Int $\mathrm{J}$ Radiat Oncol Biol Phys 13: 705-708, 1987.

15. Small $\mathrm{W}$, Mell LK, Anderson $\mathrm{P}$, et al. Consensus guidelines for the delineation of the clinical target volume for intensity modulated pelvic radiotherapy in the postoperative treatment of endometrial and cervical cancer. Int J Radiat Oncol Biol Phys 71: 428-434, 2008.

16. International Commission on Radiation Units and Measurements (ICRU) Report 38: Dose and volume specification for reporting intracavitary gynecology. 1985.

17. Haie-Meder C, Pötter R, Van Limbergen E, et al. Recommendations from Gynaecological GEC-ESTRO Working Group (I): concepts and terms in 3D image based 3D treatment planning in cervix cancer brachytherapy with emphasis on MRI assessment of GTV and CTV. Radiotherapy \& Oncology 74: 235-245, 2005.

18. Pötter R, Haie-Meder C, Van Limbergen E, et al. Recommendations from Gynaecological (GYN) GEC ESTRO Working Group (II): Concepts and Terms in 3D image based 3D treatment planning in cervix cancer brachytherapy-3D image based anatomy, radiation physics, radiobiology. Radiotherapy \& Oncology 78: 67-77, 2006.

19. Eisenhauer EA, Therasse P, Bogaerts $J$ et al. New response evaluation criteria in solid tumours: revised RECIST guideline (version 1.1). Eur J Cancer 45: 228-47, 2009

20. Cox JD, Stetz J, Pajak TF. Toxicity criteria of the Radiation Therapy Oncology Group (RTOG) and the European Organization for Research and Treatment of Cancer (EORTC). Int $J$ Radiat Oncol Biol Phys 31: 1341-1346, 1995.

21. Peters WA, Liu PY, Barrett RJ, et al. Concurrent chemotherapy and pelvic radiation therapy compared with pelvic radiation therapy alone as adjuvant therapy after radical surgery in high-risk early-stage cancer of the cervix. J Clin Oncol 18: 1606-1613, 2000.

22. Chemoradiotherapy for Cervical Cancer Meta-analysis Collaboration (CCCMAC). Reducing uncertainties about the effects of chemoradiotherapy for cervical cancer: individual patient data meta-analysis. Cochrane Database Syst Rev. CD008285, 2010.

23. Datta NR, Stutz E, Liu M et al. Concurrent chemoradiotherapy vs. radiotherapy alone in locally advanced cervix cancer: A systematic review and meta-analysis Gynecol Oncol 145: 374-385, 2017

24. Rose PG, Ali S, Watkins E, et al. Long term follow up of a randomised trial comparing concurrent single agent cisplatin, cisplatin based combination chemotherapy, or hydroxyurea during pelvic irradiation for locally advanced cervical cancer: a Gynecologic Oncology Group Study. J Clin Oncol 25: 28042810, 2007. 
25. Dueñas-González A, Zarbá JJ, Patel F, et al. Phase III, openlabel, randomized study comparing concurrent gemcitabine plus cisplatin and radiation followed by adjuvant gemcitabine and cisplatin versus concurrent cisplatin and radiation in patients with stage IIB to IVA carcinoma of the cervix. J Clin Oncol 29: 1678-1685, 2011.

26. Grigsby PW, Siegel BA, Dehdashti F, et al. Lymph node staging by positron emission tomography in patients withcarcinoma of the cervix. J Clin Oncol 19: 3745-3749, 2001

27. Schwarz JK, Siegel BA, Dehdashti F, et al. Association of posttherapy positron emission tomography with tumor response and survival in cervical carcinoma. JAMA 298: 22892295, 2007

28. Lin LL, Yang Z, Mutic S, et al. FDG-PET imaging for the assessment of physiologic volume response during radiotherapy in cervix cancer. Int J Radiat Oncol Biol Phys 65: 177-181, 2006.

29. Kim JY, Byun SJ, Kim YS, Nam JH. Disease courses in patients with residual tumor following concurrent chemoradiotherapy for locally advanced cervical cancer. Gynecol Oncol 144(1):34-39., 2017

30. Delaloye JF, Pampallona S, Coucke PA, et al. Younger age as a bad prognostic factor in patients with carcinoma of the cervix. Eur J Obstet Gynecol Reprod Biol 64: 201-205, 1996.

31. Dattoli MJ, Gretz HF, Beller U, et al. Analysis of multiple prognostic factors in patients with stage IB cervical cancer: age as a major determinant. Int J Radiat Oncol Biol Phys 17: 41-47, 1989.

32. Mitchell PA, Waggoner S, Rotmensch J, et al. Cervical cancer in the elderly treated with radiation therapy. Gynecol Oncol 71: 291-298, 1998.
33. Rose PG, Java JJ, Whitney CW, et al. Locally advanced adenocarcinoma and adenosquamous carcinomas of the cervix compared to squamous cell carcinomas of the cervix in gynecologic oncology group trials of cisplatin-based chemoradiation. Gynecol Oncol 135: 208-212, 2014.

34. Yokoi E, Mabuchi S, Takahashi R, et al. Impact of histological subtype on survival in patients with locally advanced cervical cancer that were treated with definitive radiotherapy: adenocarcinoma/adenosquamous carcinoma versus squamous cell carcinoma. J Gynecol Oncol 28: 19, 2017.

35. Jelavic TB, Mise BP, Strikic A, et al. Adjuvant chemotherapy in locally advanced cervical cancer after treatment with concomitant chemoradiotherapy-Room for improvement. Anticancer Res 35: 4161-4165, 2015.

\section{Correspondence:}

Dr. Ferah YILDIZ

Hacettepe Üniversitesi, Tip Fakültesi

Radyasyon Onkolojisi Anabilim Dali

06100 Sihhiye, ANKARA / TURKEY

Tel: (+90-312) 3052900

Fax: +90-312-309 2914

e-mail: fyildiz@hacettepe.edu.tr 